\title{
Esterification of Waste Cooking Oil using Heterogeneous Catalyst from Pearl Shell
}

\author{
*Iwan Sumarlan \& Rona Batara Mentari \\ Jurusan Kimia-MIPA-Universitas Mataram, Mataram-Indonesia 83115 \\ Received 26 June 2020, Revised 27 July 2020, Accepted 20 August 2020 \\ doi: 10.22487/j24775185.2020.v9.i3.pp183-190
}

\begin{abstract}
Biodiesel is a renewable and environmentally friendly energy source. The process of using a homogeneous catalyst has several disadvantages, such as: removing a lot of waste water from washing the catalyst residue and cannot be reused. This catalyst is also low in corrosion and is more environmentally friendly. The purpose of this study was to study the preparation of heterogeneous catalysts from pearl shells applied to the cooking oil esterification reaction. The oil was then characterized by the XRD, XRF, SEM, and FTIR. The results of GCMS for reaction without catalysts yield only $27.07 \%$ by weight of alkyl ester, whereas using a catalyst is $93.4 \%$. The influence of time, in the 60th minute, was the optimal time for the esterification reaction, and the effect of the weight of the catalyst which was $1 \%$ the optimal weight. This shows that pearl oyster shell catalyst can act as an esterification catalyst for used cooking oil and can be used as an alternative to a homogeneous catalyst substitute catalyst.
\end{abstract}

Keywords: Pearl shell, esterification, heterogenesous catalyst

\section{Pendahuluan}

Penggunaan minyak bumi sebagai bahan bakar secara terus menerus berimbas pada menipisnya cadangan minyak bumi. Pada tahun 2050 diperkirakan akan terjadi pergeseran ekonomi dari ekonomi berbasis energi fosil ke ekonomi berbasis hydrogen (Mahreni, dkk,. 2011; Pangestu \& Zultiniar, 2015) Hambatan komersialisasi hydrogen ialah pada saat ini belum ekonomis (harga hidrogen relatif lebih tinggi dibandingkan dengan bahan bakar fosil) dan pemerintah pada saat ini belum menyediakan infrastruktur untuk mendistribusikan hydrogen (Mahreni, dkk., 2011). Penelitian tentang bahan bakar alternatif berada pada profil yang tinggi di dunia untuk beberapa waktu sekarang. Biodiesel sumber energi terbarukan dan ramah lingkungan. Biodiesel memiliki bilangan setana yang tinggi dibandingkan bahan bakar diesel, tidak mengandung bahan aromatic (Wendi, 2015). Biodiesel dapat diproduksi dari minyak tumbuhan dan lemak hewan.

Biodiesel dapat diproduksi dari minyak tumbuhan bekas atau disebut minyak jelantah melalui proses esterifikasi. Esterifikasi yaitu reaksi antara asam lemak bebas dengan alkohol yang menghasilkan alkil ester (biodiesel). Secara komersil reaksi esterifikasi umumnya menggunakan katalis homogen dan bersifat asam.
Penggunaan katalis homogen pada sintesis biodiesel relatif berpotensi menimbulkan beberapa masalah, terutama jika bahan baku biodiesel berupa minyak berkadar asam lemak bebas dan air tinggi. Permasalahan yang biasanya muncul adalah terjadinya reaksi penyabunan, meningkatkan viskositas biodiesel, ketidakoptimalan yield biodiesel, dan pemisahan katalis yang relatif sulit (Mat, dkk., 2012; Chai, dkk., 2007). Hal tersebut dapat diminimalisir dengan memanfaatkan katalis heterogen.

Katalis heterogen memiliki fasa yang berbeda dengan reaktannya sehingga mudah dalam pemisahan pada tahap akhir reaksi (Adhari, dkk., 2016). Katalis padat sebagai jenis umum dari katalis heterogen, kinerjanya dalam mengkatalisasi suatu reaksi ditentukan oleh aktivitas dan selektivitasnya (Haryono, dkk., 2018). Aktivitas dan selektivitas katalis salah satunya berkaitan erat dengan sifat-sifat fisik katalis, yaitu: ukuran partikel dan distribusi ukurannya, luas permukaan, diameter pori dan distribusinya, morfologi, dan struktur katalis. Saat ini banyak industri menggunakan katalis heterogen yang mempunyai banyak keuntungan dan sifatnya yang ramah lingkungan, yaitu tidak bersifat korosif, mudah dipisahkan dari produk dengan cara filtrasi, serta dapat digunakan berulangkali dalam jangka waktu yang lama. Selain itu katalis heterogen meningkatkan

*Correspondence:

Iwan Sumarlan

e-mail: i.sumarlan@unram.ac.id

(c) 2020 the Author(s) retain the copyright of this article. This article is published under the terms of the Creative Commons Attribution License 4.0, which permits unrestricted non-commercial use, distribution, and reproduction in any medium, provided the original work is properly cited. 
kemurnian hasil karena reaksi samping dapat dieliminasi (Petrus, dkk., 2015).

Beberapa katalis heterogen yang telah digunakan pada sintesis biodiesel adalah $\mathrm{KNO}_{3} / \mathrm{Al}_{2} \mathrm{O}_{3}, \mathrm{MgO}, \mathrm{SrO}, \mathrm{CaO}$, dll. Namun $\mathrm{CaO}$ lebih banyak digunakan karena tergolong bahan yang ramah lingkungan (Tantra, dkk., 2011). Pemanfaatan $\mathrm{CaO}$ yang diperoleh dari limbah cangkang kerang telah banyak dipelajari belakangan ini seperti kerang tiram, kerang darah, kerang batik, cangkang kepiting lumpur, dan golden apple, snail shell telah digunakan sebagai sumber bahan baku $\mathrm{CaO}$ dan dievaluasi keefektifannya sebagai katalis pembuatan alkil ester.

Tingginya Kualitas dan kelimpahan biji mutiara di Lombok, menjadikan mutiara sebagai buah tangan khas Lombok. Selama 5 tahun terakhir di Nusa Tenggara Barat, sektor perikanan menempati urutan ketiga penghasil devisa dengan andalan utama biji Mutiara (Rashidi, dkk., 2012). Tingginya suplai mutiara akan berdampak pada melimpahnya limbah cangkang kerang mutiara, tetapi tidak sebanding dengan pemanfaatannya. Dikarenakan hanya dimanfaatkan sebagai souvenir. Cangkang kerang kaya dengan kalsium karbonat (CaCO) sekitar 98.5\% (Boro dkk., 2011).

$\mathrm{CaCO}_{3}$ dikonversikan menjadi $\mathrm{CaO}$ ataupun $\mathrm{Ca}(\mathrm{OH})_{2}$ dapat diaplikasikan sebagai katalis heterogen pada proses sintesis biodiesel. Dekomposisi kalsium karbonat menjadi kalsium oksida $(\mathrm{CaO})$ dan gas karbon dioksida atau $\mathrm{CO}_{2}$ dengan menggunakan metode kalsinasi. Proses kalsinasi memiliki waktu optimal selama 3-5 jam pada suhu $700-1000^{\circ} \mathrm{C}$. Penggunaan suhu tinggi saat proses kalsinasi akan mempercepat dan optimal dalam mengkonversi $\mathrm{CaCO}_{3}$. Formasi katalis akan terbentuk jika dikalsinasi pada suhu $800^{\circ} \mathrm{C}$ selama 4 jam. Adapun Indikator terbentuknya katalis yaitu abu yang dihasilkan berwarna lebih putih dari sebelum pemanasan. Maka dari itu limbah cangkang kerang yang tidak dapat dimanfaatkan sebagai souvenir, dialihkan pemanfaatannya sebagai katalis yang tidak beracun dan ramah lingkungan (Mohadi, dkk., 2016).

\section{Metode}

Bahan dan alat yang digunakan meliputi limbah cangkang kerang mutiara, minyak jelantah, metanol teknis $96 \%$, aquades, es batu dan kertas saring, labu leher tiga, hot plate, erlenmeyer, erlenmeyer, termometer $110^{\circ} \mathrm{C}$ dan $300^{\circ} \mathrm{C}$, corong pisah, kondensor, batang pengaduk, gelas kimia, magnetic stirer, timbangan analitik, cawan porselin, tanur, pipet volume, gelas ukur, ayakan 200 mesh, pipet tetes, gelas arloji, sendok, rubber bulb, botol sampel, XRD, XRF, SEM, FTIR, dan GCMS.

\section{Preparasi Katalis Cangkang Kerang Mutiara}

Limbah cangkang kerang mutiara diperoleh dari buangan industri souvenir mutiara yang berada di kecamatan Sekarbela, Mataram. Cangkang kerang mutiara yang bersih dikeringkan pada sinar matahari selama dua hari. Selanjutnya, dihancurkan menggunakan grinder dan mortar hingga berbentuk bubuk, serta dilewatkan pada ayakan dengan ukuran partikel antara 200 mesh. Serbuk cangkang kerang mutiara dikalsinasi pada suhu $800^{\circ} \mathrm{C}$ menggunakan tanur selama 4 jam. Kemudian diletakkan pada wadah hampa udara. Hasil kalsinasi kemudian dilakukan menggunakan XRD, XRF, SEM, dan FTIR.

\section{Reaksi Esterifikasi}

Esterifikasi minyak jelantah direaksikan menggunakan labu leher tiga pada set alat. Perbandingan mol antara minyak dan metanol adalah 1:15.23 gram minyak jelantah dipanaskan menggunakan hot plate selama 30 menit pada suhu $105^{\circ} \mathrm{C}$, kemudian didinginkan hingga suhu $50^{\circ} \mathrm{C}$ dan dikonstankan. Pada bagian lain katalis $\mathrm{CaO} 4 \%$ dicampurkan dengan metanol di dalam reaktor dan diaduk menggunakan magnetic stirer. Setelah katalis $\mathrm{CaO}$ dan metanol homogen dan mencapai suhu $60^{\circ} \mathrm{C}$, dimasukkan minyak jelantah yang dipanaskan sebelumnya ke dalam campuran katalis dan metanol di dalam labu leher tiga. Campuran tersebut ditransesterifikasi selama 180 menit pada suhu $60-65^{\circ} \mathrm{C}$.

Campuran dimasukkan ke dalam corong pemisah dan diendapkan selama 24 jam untuk dipisahkan antara metil ester dan gliserol, sedangkan katalis terendapkan dalam reaktor. Setelah 24 jam terbentuk dua lapisan yaitu bagian atas corong adalah metil ester (biodiesel) dan bagian bawah merupakan gliserol. Lakukan pengulang metode transesterifikasi namun tanpa menggunakan katalis, sebagai perbandingan.

\section{Analisis Hasil Transesterifikasi Menggunakan} GCMS

Hasil esterifikasi minyak jelantah tanpa katalis dan menggunakan katalis di analisis menggunakan GCMS (Gas Chromatographymass spectroscopy) untuk mengetahui apakah pada lapisan tersebut sudah terbentuk alkil ester. GCMS dikondisikan dengan suhu injector $290^{\circ} \mathrm{C}$. Kolom yang digunakan adalah RTx-65TG capillary column $(30 \mathrm{~m} \times 0.25 \mathrm{~mm}$, Supelco, USA). Suhu kolom mula-mula adalah $40^{\circ} \mathrm{C}$ dan suhu akhirnya $280^{\circ} \mathrm{C}$, dengan kenaikan suhu $8 \mathrm{c} /$ menit. Etektor yang digunakan yaitu FID (Flame Ionization Detector) dengan suhu detector $300^{\circ} \mathrm{C}$. Pembawa yang digunakan yaitu helium dengan keceptan alir $30 \mathrm{~mL} /$ menit.

\section{Variasi Pengaruh Berat Katalis dan Waktu}

Pengaruh Waktu Reaksi

Reaksi transesterifikasi dilakukan dengan campuran minyak dan etanol dengan perbandingan $1: 15$, ditambahkan katalis $4 \%$ dari 
berat minyak jelantah pada suhu $60-65^{\circ} \mathrm{C}$. Waktu reaksi divariasikan yaitu 30, 45, 60, 90, 120, 180 menit.

\section{Pengaruh Berat Katalis}

Pada studi ini, jumlah katalis yang digunakan pada proses transesterifikasi divariasikan, yaitu $0.25 \%, 0,5 \%, 1 \%, 2 \%, 3 \%$, dan $4 \%$ dari berat minyak jelantah. Lama waktu reaksi ditetapkan setelah didapatkan waktu optimal pada pengaruh waktu reaksi dengan perbandingan mol minyak dan etanol 1:15 pada suhu $60-65^{\circ} \mathrm{C}$.

\section{Hasil dan Pembahasan}

\section{Karakterisasi Cangkang Kerang Mutiara}

Data Hasil Karakterisasi Menggunakan X-Ray Difraction (XRD)

Analisis hasil kalsinasi cangkang kerang mutiara menggunakan XRD bertujuan untuk mengetahui komposisi yang terkandung dalam sampel. Adapun pola XRD yang dihasilkan sebagai berikut:

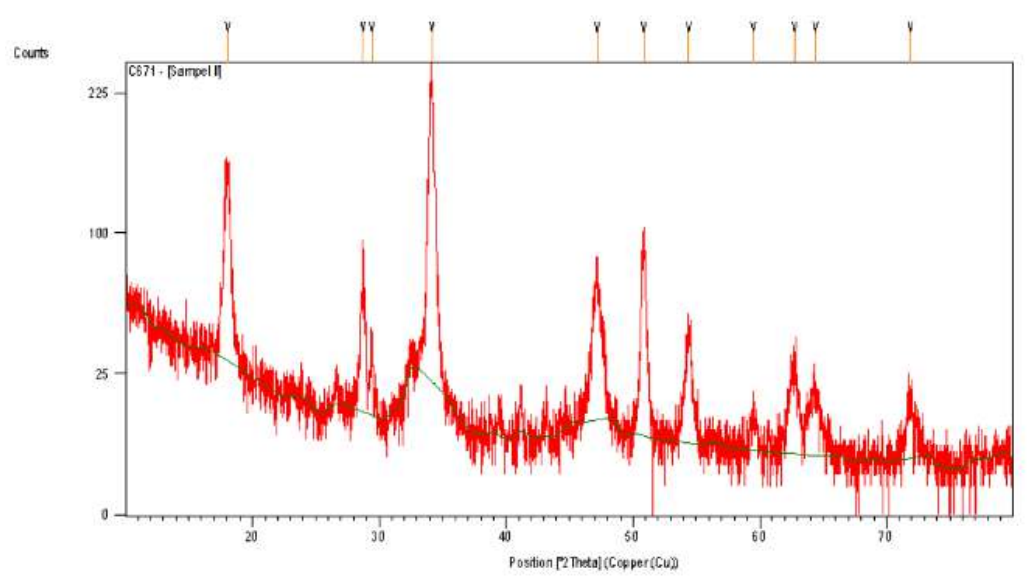

Gambar 1. Difraktogram sinar-X cangkang kerang mutiara setelah kalsinasi.

Berdasarkan pola yang dihasilkan XRD dapat dilihat bahwa terdapat kandungan $\mathrm{CaO}$, $\mathrm{Ca}(\mathrm{OH})_{2}$ dan $\mathrm{CaCO}_{3}$. Setelah dilakukan persamaan dengan rujukan standar joint commitem on power diffraction standards (JCPDS), terdapat senyawa $\mathrm{CaO}$ yang puncaknya

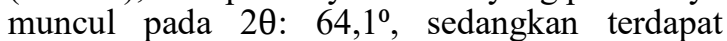
puncak $\mathrm{CaCO}_{3}$ pada 2-thetha $29,4^{\circ}$ dan $47,8^{\circ}$. Kemudian terdapat senyawa $\mathrm{Ca}(\mathrm{OH})_{2}$ pada puncak lainnya yang disamakan dengan penelitian yang dilakukan sebelumnya (Asikin, dkk., 2015), puncak $\mathrm{Ca}(\mathrm{OH})_{2}$ muncul pada $2 \theta: 28.7^{\circ}, 34.1^{\circ}$, dan $54.1^{\circ}$.

Proses kalsinasi bertujuan untuk mengkonversi $\mathrm{CaCO}_{3}$ menjadi $\mathrm{CaO}$. Namun pada hasil analisis XRD pada sampel cangkang kerang mutiara setelah kalsinasi menunjukkan adanya $\mathrm{CaO}, \mathrm{Ca}(\mathrm{OH})_{2}$, dan $\mathrm{CaCO}_{3}$. Terbentuknya $\mathrm{Ca}(\mathrm{OH})_{2}$ disebabkan karena penyimpanan sampel hasil kalsinansi tidak dilakukan di tempat yang kering seperti di dalam desikator. $\mathrm{CaO}$ yang terbentuk dari hasil kalsinasi mudah mengikat molekul air karena bersifat higroskopis sehingga membentuk $\mathrm{Ca}(\mathrm{OH})_{2}$.

\section{Data Hasil Karakterisasi Menggunakan X-Ray Fluorescence (XRF)}

Pengujian menggunakan XRF bertujuan untuk melihat unsur yang terkandung di dalam cangkang kerang mutiara sebelum dan sesudah dikalsinasi dikalsinasi. Pengukuran dengan alat XRF didasarkan pada energi emisi yang dihasilkan dari pengisian kekosongan elektron yang berasal dari elektron luar. Oleh karena besarnya nilai emisi ini khas untuk atom tertentu maka dapat digunakan untuk analisis. Secara kuantitatif, persentase kandungan unsur penyusun cangkang mutiara sebelum dikalsinasi ditampilkan pada Tabel 1 .

Dilihat dari persentasi sebelum kalsinasi bahwa pada cangkang kerang mutiara telah terdapat $\mathrm{CaO}$ dalam jumalh yang tinggi yaitu $91.71 \%$, sedangkan sisanya yaitu logam lainnya sebanyak 8.29\%. Dari data tersebut dapat memperkuat cangkang kerang mutiara dapat menghasilkan konversi $\mathrm{CaO}$ dari $\mathrm{CaCO}_{3}$ yang sangat tinggi. Adapun hasil analisis XRF setelah kalsinasi ditampilkan pada Tabel 2 
Tabel 1. Hasil XRF sebelum kalsinasi

\begin{tabular}{ccc}
\hline Nomor Atom & Rumus Kimia & $\%$ \\
\hline 20 & $\mathrm{Ca}$ & 91.71 \\
49 & $\mathrm{In}$ & 2.30 \\
26 & $\mathrm{Fe}$ & 2.07 \\
14 & $\mathrm{Si}$ & 1.60 \\
42 & $\mathrm{Mo}$ & 0.87 \\
38 & $\mathrm{Sr}$ & 0.79 \\
56 & $\mathrm{Ba}$ & 0.20 \\
71 & $\mathrm{Lu}$ & 0.19 \\
22 & $\mathrm{Ti}$ & 0.18 \\
82 & $\mathrm{~Pb}$ & 0.06 \\
25 & $\mathrm{Mn}$ & 0.06 \\
33 & $\mathrm{As}$ & 0.05 \\
\hline
\end{tabular}

Tabel 2. Hasil XRF setelah kalsinasi

\begin{tabular}{ccc}
\hline Nomor Atom & Rumus Kimia & $\%$ \\
\hline 20 & $\mathrm{Ca}$ & 95.29 \\
\hline 26 & $\mathrm{Fe}$ & 1.64 \\
\hline 14 & $\mathrm{Si}$ & 0.99 \\
\hline 38 & $\mathrm{Sr}$ & 0.67 \\
\hline 70 & $\mathrm{Yb}$ & 0.51 \\
\hline 16 & $\mathrm{~S}$ & 0.27 \\
\hline 56 & $\mathrm{Ba}$ & 0.20 \\
\hline 71 & $\mathrm{Lu}$ & 0.10 \\
\hline 22 & $\mathrm{Ti}$ & 0.10 \\
\hline 25 & $\mathrm{Mn}$ & 0.06 \\
\hline 82 & $\mathrm{~Pb}$ & 0.06 \\
\hline 33 & $\mathrm{As}$ & 0.05 \\
\hline 29 & $\mathrm{Cu}$ & 0.04 \\
\hline
\end{tabular}

Pada Tabel 2, persentase Ca pada hasil kalsinasi sebesar $95.29 \%$, angka tersebut lebih tinggi dibandingkan sebelum kalsinasi. Hal ini disebabkan oleh penghilangan unsur pengotor pada cangkang kerang dan menyisakan $\mathrm{CaO}$ yang lebih murni. Terdapat pula logam-logam lainnya, perbandingan persentase jumlah logam lainnya sebelum dan sesudah kalsinasi semakin menurun yaitu bersisa $4.71 \%$ dari berat total.

Data Hasil Karakterisasi Menggunakan FTIR

Pengukuran FTIR dilakukan dengan tujuan untuk mengidentifikasi gugus fungsi yang terdapat dalam suatu senyawa. Analisis FTIR terhadap sampel dilakukan pada bilangan gelombang 300-4000 $\mathrm{cm}^{-1}$. Spektra FTIR cangkang kerang mutiara hasil kalsinasi disajikan pada Gambar 2.

Hasil analisis FTIR pada sampel cangkang kerang mutiara sebelum kalsinasi (Gambar. 2a) menunjukkan adanya ikatan O-C-O streching dari karbonat yang muncul pada bilangan gelombang $1788.44 \mathrm{~cm}$ yang diperkuat oleh hadirnya puncak pada $1082.72 \mathrm{~cm}^{-1}$. Intensitas puncak pada sebelum kalsinasi yaitu pada bilangan $626.07 \mathrm{~cm}^{-1}$ menurun, kemudian hanya menyisakan satu puncak pada bilangan gelombang $875 \mathrm{~cm}^{-1}$ setelah kalsinasi. 

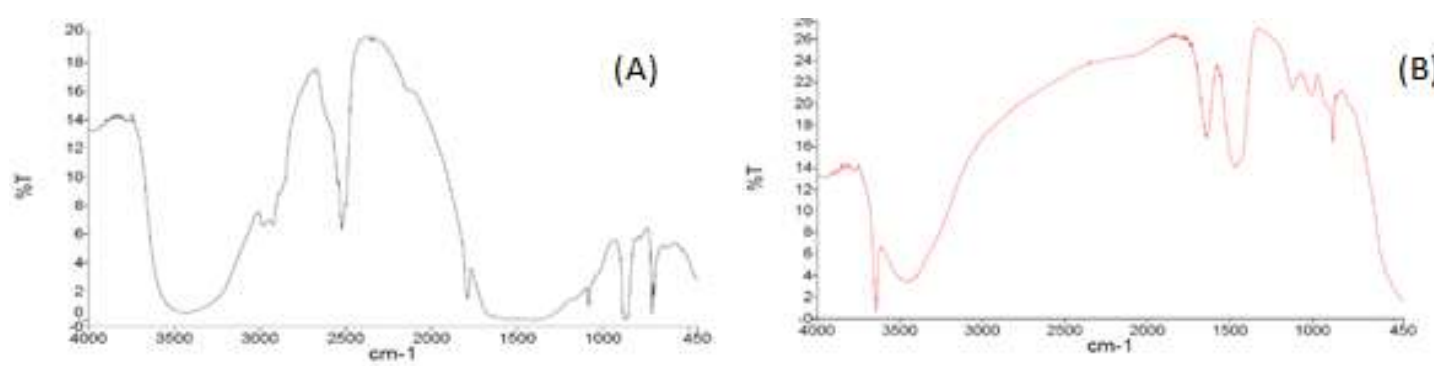

Gambar 2. Analisa FTIR sebelum (A) dan setelah kalsinasi (B).

Pada hasil analisis FTIR setelah kalsinasi maka didapatkan $\mathrm{CaO}$ dengan munculnya puncak yang tajam pada bilangan gelombang $875 \mathrm{~cm}^{-1}$. Pita dari gugus $\mathrm{OH}$ juga muncul dibilangan gelombang 3779.56. Adanya gugus $\mathrm{OH}$ dari $\mathrm{Ca}(\mathrm{OH})_{2}$ dengan karakteristik puncak yang tajam di daerah $3643.33 \mathrm{~cm}^{-1}$ dimungkinkan berasal dari molekul air yang teradsorbsi pada permukaan

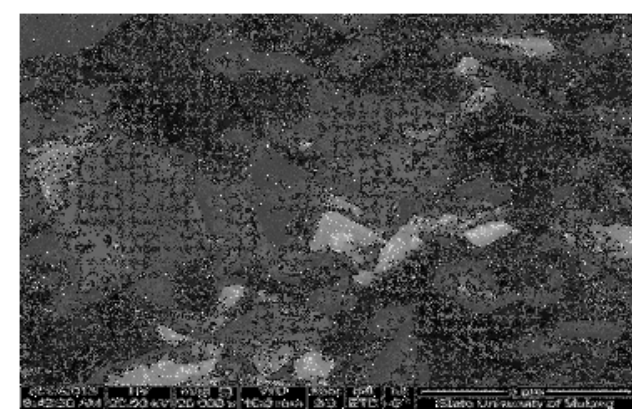

(a)
$\mathrm{CaO}$, di mana $\mathrm{CaO}$ dikenal bersifat higroskopis sehingga sangat mudah menyerap uap air dari udara.

\section{Data Hasil Karakterisasi Menggunakan Scanning Electron Microscope (SEM)}

Untuk mendapatkan informasi lebih lanjut tentang morfologi katalis abu kulit kerang, analisis dengan SEM juga dilakukan.

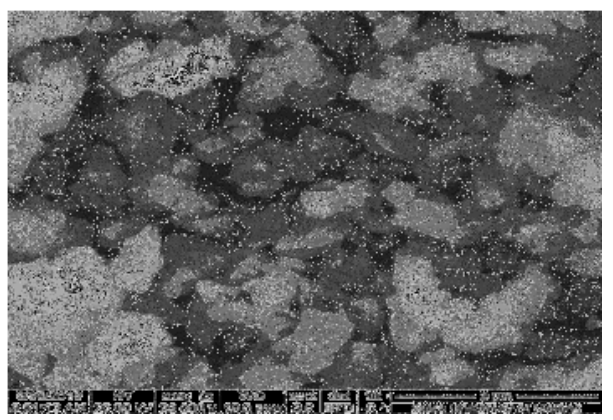

(b)

Gambar 3. SEM sampel (a) sebelum kalsinasi dan (b) setelah kalsinasi (magnifikasi 20.000x)

Abu cangkang kerang mutiara sebelum kalsinasi terlihat partikel-partikel yang terbentuk tidak teratur dengan ukuran yang tidak merata. Sedangkan bentuk partikel yang sudah dikalsinasi memiliki bentuk yang seragam. Fenomena ini mengisyaratkan bahwa pengaruh kalsinasi abu kulit kerang pada suhu tinggi, selain menyebabkan konversi $\mathrm{CaCO}_{3}$ menjadi $\mathrm{CaO}$, juga ukuran partikel menjadi seragam dan distribusi partikel lebih teratur. Struktur gumpalan atau aglomeasi tersebut menunjukkan adanya logam oksida yang terbentuk.

\section{Hasil Analisis GCMS}

Pengujian menggunakan GCMS dilakukan untuk mengetahui senyawa yang terkandung dari hasil reaksi transesterifikasi. Pengujian dilakukan terhadap dua sampel hasil esterifikasi yaitu tanpa penambahan katalis dan penambahan katalis 4\%. Sehingga dapat membandingkan hasil penambahan katalis dan tanpa katalis. Adapun hasil GCMS sebagai berikut:

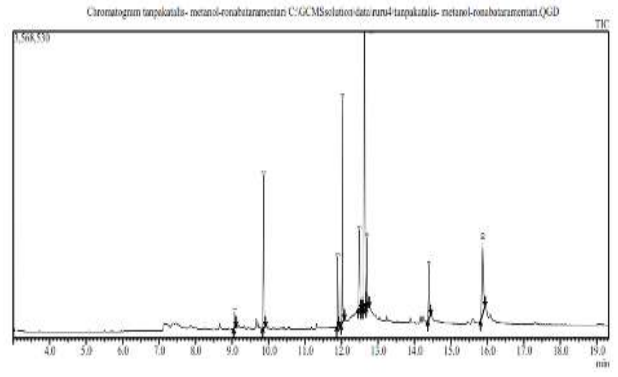

Gambar 4. Hasil Analisis GCMS transesterifikasi tanpa penambahan katalis 
Merujuk hasil GCMS sampel tanpa penambahan katalis, terdapat sepuluh puncak yang muncul pada kromatogram. Berdasarkan sepuluh puncak tersebut hanya ada lima puncak yang menunjukkan terdapat alkil ester. Dapat dilihat pula bahwa hampir seluruh puncak tertinggi bukan alkil ester. Persen berat alkil ester yang dihasilkan hanya $27.07 \%$ dan sisanya $72.93 \%$ merupakan senyawa lainnya. Sedikitnya terbentuk alkil ester disebabkan reaksi yang tidak bergeser kearah produk. Kemudian waktu 3 jam tidak cukup untuk reaksi transesterifikasi tanpa katalis, katalis dibutuhkan untuk mempercepat jalannya reaksi dan membantu reaksi mengarah ke produk. Maka dari itu dilakukan perbandingan dengan menganalisis kandungan fase alkil ester dari hasil reaksi transesterifikasi ditambahkan katalis $4 \%$, namun waktu dan perbandingan mol metanol dan minyak sama seperti perlakuan transesterifikasi tanpa katalis. Berikut ini adalah data kromatogram GCMS:

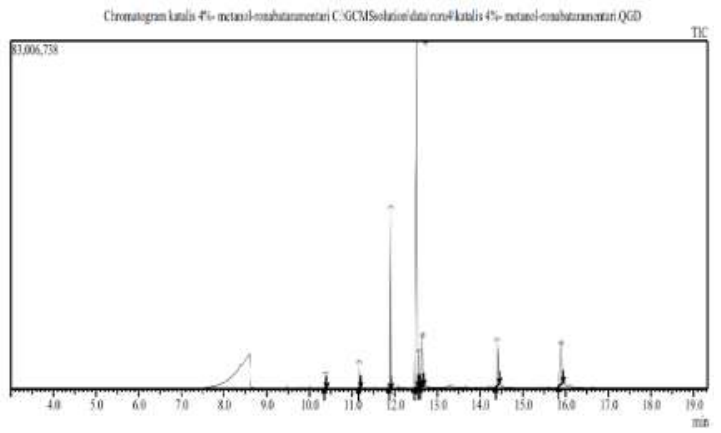

Gambar 5. Hasil GCMS transesterifikasi penambahan katalis $4 \%$

Dapat dilihat dari hasil persen berat alkil ester yang dihasilkan yaitu $93.4 \%$ dan senyawa lain $6.6 \%$. Persentase yang didapatkan jauh lebih besar dari reakti tanpa menggunakan katalis, Hal ini menunjukkan bahwa penambahan katalis pada reaksi transesterifikasi sangat berpengaruh meskipun lama waktu reaksi cepat. Katalis basa Penggunaan katalis basa akan menjadikan laju reaksinya 4000 kali lebih cepat dibandingkan dengan menggunakan katalis asam. Perbedaan signifikan dalam kecepatan reaksi ini dikarenakan dengan menggunakan katalis basa reaksi akan berlangsung satu arah (irreversible) sehingga arah reaksi hanya ke produk. Sedangkan jika menggunakan katalis asam, maka reaksi akan berlangsung dua arah (reversible). Keaktifan katalis ditentukan oleh alkalinitas dan jumlah gugus basanya (Zhang dkk., 2010).

\section{Pengaruh Lama Waktu Esterifikasi}

Pengaruh waktu reaksi transesterifikasi terhadap $\%$ yield dipelajari pada waktu $45,60,90$, dan 120 menit dengan variabel lain ditetapkan yaitu jumlah katalis 4\% dan rasio minyak dengan metanol 1:15. Hasil percobaan disajikan pada Gambar 6:

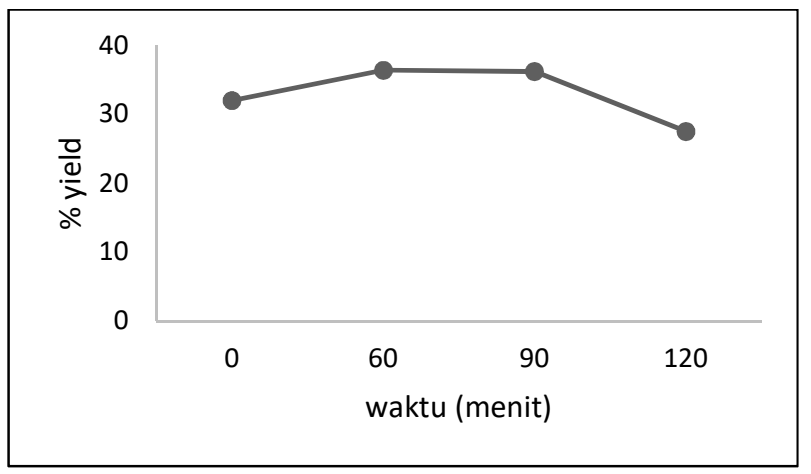

Gambar 6. Pengaruh waktu terhadap \% yield

Pada waktu 45 menit ke 60 menit mengalami peninggkatan $\%$ yield, hal ini dikarenakan pada menit ke 45 menit seluruh reaktan belum beraksi sempurna membentuk produk. Kemudian menit ke 60 hingga ke 120 menit terjadi penurunan $\%$ yield. Hal ini disebabkan karena pada waktu yang terlalu lama, sehingga yield yang terbentuk tidak mengalami kenaikan yang signifikan. Dari Gambar diatas yield tertinggi untuk reaksi tersebut adalah pada 
waktu transesterifikasi 60 menit, apabila waktu transesterifikasi dilanjutkan, kemungkinan yield akan mengalami penurunan. hal ini juga kemungkinan disebabkan waktu setelah optimum merupakan waktu saat dimana kesetimbangan reaksi transesterifikasi tercapai.

\section{Pengaruh Berat Katalis}

Pengaruh berat katalis pada reaksi transesterifikasi terhadap \% yield dipelajari pada berat $0.12 ; 0.23 ; 0.46 ; 0.69$ dengan variabel lain ditetapkan yaitu lama waktu reaksi 60 menit dan rasio minyak dengan metanol 1:15. Hasil percobaan disajikan pada Gambar 7.

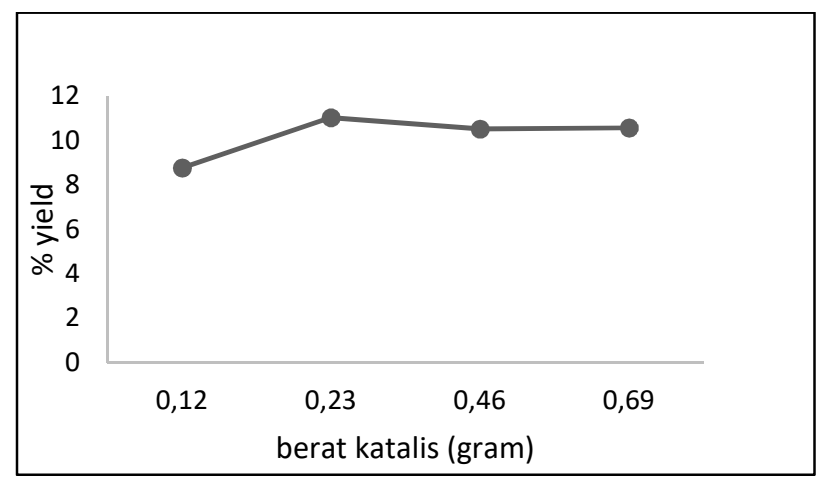

Gambar 7. Pengaruh berat katalis terhadap \% yield

yield yang paling tinggi dari semua sampel diatas adalah dengan menggunakan katalis $\mathrm{CaO} 0.23$ gr dengan $\%$ yield yang dihasilkan yaitu $48 \%$. Sedangkan mengalami penurunan pada penambahan katalis selanjutnya. Bertambahnya jumlah katalis akan memberikan pengaruh pengkonversian asam lemak menjadi ester. Dapat dilihat semakin banyak jumlah katalis $\mathrm{CaO}$ pada reaksi esterifikasi maka yield biodiesel semakin menurun. secara keseluruhan, semakin banyak penggunaan katalis, tidak menghasilkan FAME yang semakin besar.

\section{Kesimpulan}

Uji XRD menunjukkan keberadaan senyawa $\mathrm{CaO}$ yang puncaknya muncul pada $2 \theta$ : $64.1^{\circ}$ dan senyawa $\mathrm{Ca}(\mathrm{OH})_{2}$ muncul pada puncak 20: $28.7^{\circ}, \quad 34.1^{\circ}$, dan $54.1^{\circ}$. Sedangkan berdasarkan hasil uji XRF kandungan $\mathrm{Ca}$ pada sampel yang sudah dikalsinasi sangat tinggi dibandingkan dengan sebelum kalsinasi yaitu $95.29 \%$. Kemudian diperkuat hasil analisis FTIR setelah kalsinasi maka didapatkan $\mathrm{CaO}$ dengan munculnya puncak yang tajam pada bilangan gelombang $875 \mathrm{~cm}^{-1}$. Hasil uji SEM, abu cangkang kerang mutiara sebelum kalsinasi terlihat partikelpartikel yang terbentuk tidak teratur dengan ukuran yang tidak merata. Sedangkan bentuk partikel yang sudah dikalsinasi memiliki bentuk yang seragam Analisis Hasil esterifikasi dengan menggunakan GC-MS yaitu untuk reaksi tanpa katalis menghasilkan persen berat alkil ester yang dihasilkan hanya 27.07\%. Sedangkan menggunakan katalis yaitu 93.4\%. Waktu 60 menit merupakan waktu yang optimal untuk reaksi esterifikasi, dan pengaruh berat katalis yaitu $1 \%$ merupakan berat optimal. Hal ini menunjukkan bahwa katalis cangkang kerang mutiara dapat berperan sebagai katalis untuk esterifikasi minyak jelantah dan dapat digunakan sebagai alternatif katalis pengganti katalis homogen yang bersifat asam.

\section{Ucapan Terima Kasih}

Penulis mengucapkan terima kasih kepada Universitas Mataram yang telah membantu dan mendukung selama proses penelitian.

\section{Referensi}

Adhari, H., Yusnimar, \& Utami, S. P. (2016). Pemanfaatan minyak jelantah menjadi biodiesel dengan katalis $\mathrm{ZnO}$ presipitan zinc karbonat: Pengaruh waktu reaksi dan jumlah katalis. Jurnal Online Mahasiswa Fakultas Teknik Universitas Riau, 3(2),1-7.

Asikin-Mijan, N., Taufiq-Yap, Y. H., \& Lee, H. V. (2015). Synthesis of clamshell derived $\mathrm{Ca}(\mathrm{OH})_{2}$ nano-particles via simple surfactanthydration treatment. Chemical Engineering Journal, 262, 1043-1051.

Boro, J., Thakur, A. J., \& Deka, D. (2011). Solid oxide derived from waste shells of turbonilla striatula as a renewable catalyst for biodiesel production. Fuel Processing Technology, 92(10), 2061-2067.

Chai, F., Fenghua, C., Fengying, Z., Yang, C., Xiaohong, W., \& Zhongmin, S. (2007). Transesterification of vegetable oil to biodiesel using a heteropolyacid solid catalyst. Advanced Synthesis and Catalysis, 349(7), 1057-1065.

Haryono, H., Natanael, C. L., Rukiah, R., \& Yulianti, Y. B. (2018). Kalsium oksida mikropartikel dari cangkang telur sebagai katalis pada sintesis biodiesel dari minyak 
goreng bekas. Jurnal Material dan Energi Indonesia, 8(1), 8-15.

Mahreni, M., Mohamad, A. B., Kadhum, A. A. H., \& Daud, W. R. W. (2011). Advances in nanocomposites - synthesis, characterization and industrial aplication. China: InTech.

Mahreni, \& Sulistyawati, E. (2011). Pemanfaatan kulit telur sebagai katalis biodisel dari minyak sawit dan metanol. Seminar Rekayasa Kimia Dan Proses. Semarang: Jurusan Teknik Kimia, Fakultas Teknik Universitas Diponegoro.

Mat, R., Samsudin, R. A., Mohamed, M., \& Johari, A. (2012). Solid catalysts and their application in biodiesel production. Bulletin of Chemical Reaction Engineering \& Catalysis, 7(2), 142-149.

Mohadi, R., Anggraini, K., Riyanti, F., \& Lesbani, A. (2016). Preparation calcium oxide from chicken eggshells. Sriwijaya Journal of Environment, 1(2), 32-35.

Pangestu, W., \& Zultiniar, Y. (2015). Perengkahan katalitik palm fatty acid distillate menjadi biofuel menggunakan fly ash sawit. Jurnal Online Mahasiswa Fakultas Teknik Universitas Riau, 2(1), 1-5.
Petrus, B., Sembiring, A. P., \& Sinaga, M. S (2015). Pemanfaatan abu cangkang kerang darah (anadara granosa) sebagai katalis dalam pembuatan metil ester dari minyak jelantah. Jurnal Teknik Kimia Universitas Sumatera Utara, 4(2), 13-19.

Rashidi, N. A., Mohamed, M., \& Yusup, S. (2012). The kinetic model of calcination and carbonation of anadara granosa. International Journal of Renewable Energy Research, 2(3), 497-503.

Tantra, H. D., Tandean, E., Indraswati, N., \& Ismadji, S. (2011). Katalis dari limbah kerang batik (phapia undulata) untuk pembuatan biodiesel dari minyak kelapa sawit. Prosiding Seminar Nasional Fundamental dan Aplikasi Teknik Kimia, 1-4. Surabaya.

Wendi, V. C. (2015). Pengaruh suhu reaksi dan jumlah katalis pada pembuatan biodiesel dari limbah lemak sapi dengan menggunakan katalis heterogen $\mathrm{CaO}$ dari kulit telur ayam. Jurnal Teknik Kimia Universitas Sumatera Utara, 4(1), 35-41.

Zhang, J., Chen, S., Yang, R., \& Yan, Y. (2010). Biodiesel production from vegetable oil using heterogenous acid and alkali catalyst. Fuel, 89(10), 2939-2944. 